A folyóirat recenzensei/lektorai 2016-ban

Recenzenti časopisa u 2016. godini

Peer-Reviewers in 2016

\title{
dr. BARCSI Tamás
}

Pécsi Tudományegyetem, Egészségtudományi Kar, Pécs, Magyarország

Univerzitet u Pečuju, Fakultet medicinskih nauka, Pečuj, Mađarska

University of Pécs, Faculty of Health Sciences,

Pécs, Hungary

dr. BENCE Erika

Újvidéki Egyetem, Bölcsészettudományi Kar,

Újvidék, Szerbia

Univerzitet u Novom Sadu, Filozofski fakultet,

Novi Sad, Srbija

University of Novi Sad, Faculty of Philosophy,

Novi Sad, Serbia

dr. BORDÁS Sándor

Eötvös József Főiskola, Pedagógusképző Intézet,

Baja, Magyarország

Viša škola „Jožef Etveš”, Institut za pedagogiju,

Baja, Mađarska

College Eötvös József, Institute of Education,

Baja, Hungary

dr. CSERNICSKÓ István

II. Rákóczi Ferenc Kárpátaljai Magyar Főiskola,

Beregszász, Ukrajna

Transkarpatska mađarska viša škola „Ferenc Rakoci II“,

Berehove, Ukrajna

Ferenc Rákóczi II. Transcarpathian Hungarian Institute,

Berehove, Ukraine 


\section{dr. ERDÉLY Judit}

Sapientia Erdélyi Magyar Tudományegyetem, Csíkszeredai Kar, Csíkszereda, Románia

Mađarski univerzitet „Sapientia”, Fakultet u Miercurea Ciucu, Miercurea Ciuc, Rumunija

Sapientia Hungarian University of Transylvania, Faculty of Economic, Socio-Human Sciences and Engineering,

Miercurea Ciuc, Romania

dr. HARKAI VASS Éva

Újvidéki Egyetem, Bölcsészettudományi Kar,

Újvidék, Szerbia

Univerzitet u Novom Sadu, Filozofski fakultet, Novi Sad, Srbija

University of Novi Sad, Faculty of Philosophy, Novi Sad, Serbia

dr. HORVÁTH FUTÓ Hargita

Újvidéki Egyetem, Bölcsészettudományi Kar,

Újvidék, Szerbia

Univerzitet u Novom Sadu, Filozofski fakultet, Novi Sad, Srbija

University of Novi Sad, Faculty of Philosophy, Novi Sad, Serbia

\section{dr. ISPÁNOVICS CSAPÓ Julianna}

Újvidéki Egyetem, Bölcsészettudományi Kar, Újvidék, Szerbia

Univerzitet u Novom Sadu, Filozofski fakultet, Novi Sad, Srbija

University of Novi Sad, Faculty of Philosophy, Novi Sad, Serbia

dr. KARLOVITZ János Tibor

Óbudai Egyetem, Keleti Károly Gazdasági Kar, Budapest, Magyarország

Univerzitet u Starom Budimu, Privredni fakultet „Karolj Keleti“, Budimpešta, Mađarska

Óbuda University, Keleti Faculty of Business and Management, Budapest, Hungary 
dr. KATONA Edit

Újvidéki Egyetem, Bölcsészettudományi Kar,

Újvidék, Szerbia

Univerzitet u Novom Sadu, Filozofski fakultet,

Novi Sad, Srbija

University of Novi Sad, Faculty of Philosophy,

Novi Sad, Serbia

dr. KISS Attila

Szegedi Tudományegyetem, Bölcsészettudományi Kar,

Szeged, Magyarország

Univerzitet u Segedinu, Filozofski fakultet,

Segedin, Mađarska

University of Szeged, Faculty of Arts,

Szeged, Hungary

dr. KOVÁCS RÁCZ Eleonóra

Újvidéki Egyetem, Bölcsészettudományi Kar,

Újvidék, Szerbia

Univerzitet u Novom Sadu, Filozofski fakultet,

Novi Sad, Srbija

University of Novi Sad, Faculty of Philosophy,

Novi Sad, Serbia

\section{dr. P. LAKATOS Ilona}

Nyíregyházi Egyetem, Magyar Nyelvészeti Intézeti Tanszék,

Nyíregyháza, Magyarország

Univerzitet u Njiređhazi, Filozofski fakultet,

Njiređhaza, Mađarska

College of Nyíregyháza, Faculty of Arts,

Nyíregyháza, Hungary

dr. LÁNCZ Irén

Újvidéki Egyetem, Bölcsészettudományi Kar,

Újvidék, Szerbia

Univerzitet u Novom Sadu, Filozofski fakultet,

Novi Sad, Srbija

University of Novi Sad, Faculty of Philosophy,

Novi Sad, Serbia 
dr. MEDVE Zoltán

Eszéki J. J. Strossmayer Egyetem, Bölcsészettudományi Kar,

Eszék, Horvátország

Filozofski fakultet Sveučilišta J. J. Strossmayera u Osijeku,

Osijek, Hrvatska

J. J. Strossmayer University of Osijek, Faculty of Humanities and Social Sciences,

Osijek, Croatia

dr. NÉMETH Miklós

Szegedi Tudományegyetem, Bölcsészettudományi Kar,

Szeged, Magyarország

Univerzitet u Segedinu, Filozofski fakultet,

Segedin, Mađarska

University of Szeged, Faculty of Arts,

Szeged, Hungary

dr. NOVÁK Anikó

Újvidéki Egyetem, Bölcsészettudományi Kar,

Újvidék, Szerbia

Univerzitet u Novom Sadu, Filozofski fakultet,

Novi Sad, Srbija

University of Novi Sad, Faculty of Philosophy,

Novi Sad, Serbia

\section{dr. PÁLFALVI Lajos}

Pázmány Péter Katolikus Egyetem, Bölcsészet- és Társadalomtudományi Kar,

Piliscsaba, Magyarország

Univerzitet „Peter Pazmanj“, Fakultet za filozofske i društvene nauke,

Piliščaba, Mađarska

Pázmány Péter University, Faculty of Humanities and Social Sciences,

Piliscsaba, Hungary

dr. PAPP Ágnes Klára

Károli Gáspár Református Egyetem, Bölcsészettudományi Kar,

Budapest, Magyarország

Reformatski univerzitet „Gašpar Karoli“, Filozofski fakultet,

Budimpešta, Mađarska

Károli Gáspár University of the Reformed Church in Hungary, Faculty of Humanities, Budapest, Hungary 


\section{dr. PÁSZTOR KICSI Mária}

Újvidéki Egyetem, Bölcsészettudományi Kar,

Újvidék, Szerbia

Univerzitet u Novom Sadu, Filozofski fakultet, Novi Sad, Srbija

University of Novi Sad, Faculty of Philosophy,

Novi Sad, Serbia

dr. RAJSLI Ilona

Újvidéki Egyetem, Bölcsészettudományi Kar,

Újvidék, Szerbia

Univerzitet u Novom Sadu, Filozofski fakultet, Novi Sad, Srbija

University of Novi Sad, Faculty of Philosophy,

Novi Sad, Serbia

\section{dr. SCHILLER Erzsébet}

Nyugat-magyarországi Egyetem, Savaria Egyetemi Központ,

Szombathely, Magyarország

Univerzitet „Zapadna Mađarska“, Univerzitetski centar „Savaria“,

Sombathelj, Mađarska

University of West Hungary, Savaria University Centre,

Szombathely, Hungary

dr. TÓTH I. János

Szegedi Tudományegyetem, Bölcsészettudományi Kar,

Szeged, Magyarország

Univerzitet u Segedinu, Filozofski fakultet,

Segedin, Mađarska

University of Szeged, Faculty of Arts,

Szeged, Hungary

\section{dr. VIRÁG Zoltán}

Szegedi Tudományegyetem, Bölcsészettudományi Kar,

Szeged, Magyarország

Univerzitet u Segedinu, Filozofski fakultet,

Segedin, Mađarska

University of Szeged, Faculty of Arts,

Szeged, Hungary 
dr. ZELLIGER Erzsébet

Eötvös Loránd Tudományegyetem, Bölcsészettudományi Kar,

Budapest, Magyarország

Univerzitet „Etveš Lorand“, Fakultet humanističkih nauka,

Budimpešta, Mađarska

Loránd Eötvös University, Faculty of Humanities,

Budapest, Hungary 